\title{
Exposure assessment of the radon in residential tap water in Kastamonu
}

\author{
A. Kurnaz ${ }^{*}$ and M. Atıf Çetiner \\ Department of Physics, Faculty of Arts and Sciences, Kastamonu University, 37100 Kastamonu, Turkey
}

\section{- Short report}

\author{
*Corresponding author: \\ Dr. Asil Kurnaz, \\ Fax: + 903662154969 \\ E-mail: \\ akurnaz@kastamonu.edu.tr \\ Revised: Oct. 2015 \\ Accepted: Nov. 2015 \\ Int. J. Radiat. Res., July 2016; \\ 14(3): 245-250 \\ DOI: 10.18869 /acadpub.ijrr.14.3.245
}

\begin{abstract}
Background: It is considered that if radon gas is inhaled and ingested, it is the primary health risks for lung and stomach cancers. This paper presents the measurement results of radon activity concentrations both residential tap water and dam water for Kastamonu city Centre-Turkey. Materials and Methods: The radon activity concentrations of water samples collected from 60 tap waters at four locations and 12 dam water of study area were determined. Radon concentrations were measured using the professional radon monitor AlphaGUARD PQ2000 PRO (Genitron Instruments). Results: The mean value for all residential tap water samples and dam water samples were ascertained as $0.050 \mathrm{~Bq} \mathrm{l}^{-1}$ and $0.741 \mathrm{~Bq} \mathrm{l}^{-1}$, respectively. The annual effective doses were calculated for the inhalation of radon released to air when water is used and the ingestion of drinking water. The mean values for inhalation and ingestion were found to be $0.1266 \mu \mathrm{Sv} \mathrm{y}^{-1}$ and $0.0105 \mu \mathrm{Sv} \mathrm{y}^{-1}$, respectively. For the radon exposure from ingestion, the annual effective doses were calculated for infants, children, and adults, separately. Conclusion: When the results compared with the internationally recommended safe limits, the tap waters of Kastamonu city Centre is safe for drinking purposes in terms of radon activity concentrations.
\end{abstract}

Keywords: Radon exposure, tap water, effective dose, Kastamonu.

\section{INTRODUCTION}

Human beings are exposed to natural radiation constantly everywhere. The exposure of human body from natural radiation sources is external and internal. Internal exposures originate from the intake of naturally occurring radioactive materials (NORM) by inhalation and ingestion. The major contribution to this human exposure comes from Radon $\left({ }^{222} \mathrm{Rn}\right)$. Radon and its short-lived decay products constitute about $53 \%$ of the total dose originating from natural sources (1). Radon is the heaviest, colorless, odorless and tasteless and only radioactive member of noble gas group with a half-life of 3.82 days. It belongs to the $238 \mathrm{U}$ decay series. Radon is present in soil, rocks, building materials and waters. Radon can get into the human body through inhalation radon in the air and ingestion radon in drinking water. Radon and its daughter emit ionizing alpha and beta radiations that may cause cancers in human organs $(2,3)$.

Radon is soluble gas in the water, thus the radon gas generated of the decay of uranium in the rocks and soil underground can easily pass underground water sources. Radon is similar to carbon dioxide in a soda bottle that is dissolved and then released when soda bottle is opened. Some radon may be left in the water and also, soil, building materials and underground water are the main sources of radon gas emanation (4). Therefore, domestic water can make variable contributions to indoor radon level (5). Radon concentrations can be highly significant for health risk especially at certain regions which drinking water comes from underground sources and where uranium-rich rocks situated. 
According to USEPA (2010), the primary health risks from radon in drinking water are lung cancer, from inhaling radon discharged from water used in the home, and stomach cancer, from ingesting radon in drinking water (6). When radon is inhaled or ingested, the alpha particles from its radioactive decay can interact with the biological tissues leading to DNA damage (7). Because of all these reasons, the evaluation studies of the radiation dose from radon ingestion and inhalation in drinking water are conducted continuously all over the World. All of these studies are improving the understanding of the environmental processes that effect radon exposure.

The aim of this study is to describe the findings from ${ }^{222} \mathrm{Rn}$ activity concentrations of residential tap water samples for drinking purposes and to determine the annual effective dose due to waterborne radon in Kastamonu city Centre. Also, this region is the 1st degree earthquake zone (8). The results obtained from this study will contribute to a database of environmental radioactivity measurements and will be useful for assessing of safety of the drinking water.

\section{MATERIALS AND METHODS}

\section{Study area}

Kastamonu is a city on the western Black sea region of Turkey and this region is an earthquake zone (figure 1).

The province has a total area of $13,108 \mathrm{~km}^{2}$ and it is bordered by the provinces of Bartın, Karabük, Çankırı Çorum and Sinop. In accordance with statistics in Republic of Turkey, Kastamonu Governorship, the total area is $74.6 \%$ mountains and forests, $21.6 \%$ plateaus and $3.8 \%$ plains. The population of the city is about 368,000 . The latitude and longitude of Kastamonu city are $41^{\circ} 21^{\prime} \mathrm{N}$ and $33^{\circ} 46^{\prime} \mathrm{E}$, the altitude is $775 \mathrm{~m}$ above sea level. The mean annual rainfall is about 461, $6 \mathrm{~mm}$ for the area (9). In Kastamonu, the household water is supplied from Karacomak Dam which is filled by water from surroundings streams and rainwater.

\section{Radon activity in water}

The study area is divided into 4 regions namely as Kuzeykent, City Centre, Esentepe and Olukbaşı, respectively and 15 water samples were taken from each region. Total 60 residential tap water measurements have been performed in city Centre of Kastamonu province. Sampling was done at random depending on who permitted us to carry out the study in his or her house. Water taps were opened for 5 minutes and water poured down the drain before sampling. Tap water samples were collected in 0.51 linear polypropylene bottles and these bottles were completely filled slowly and immediately closed tightly under the water in order to avoid air bubbles. In addition, the

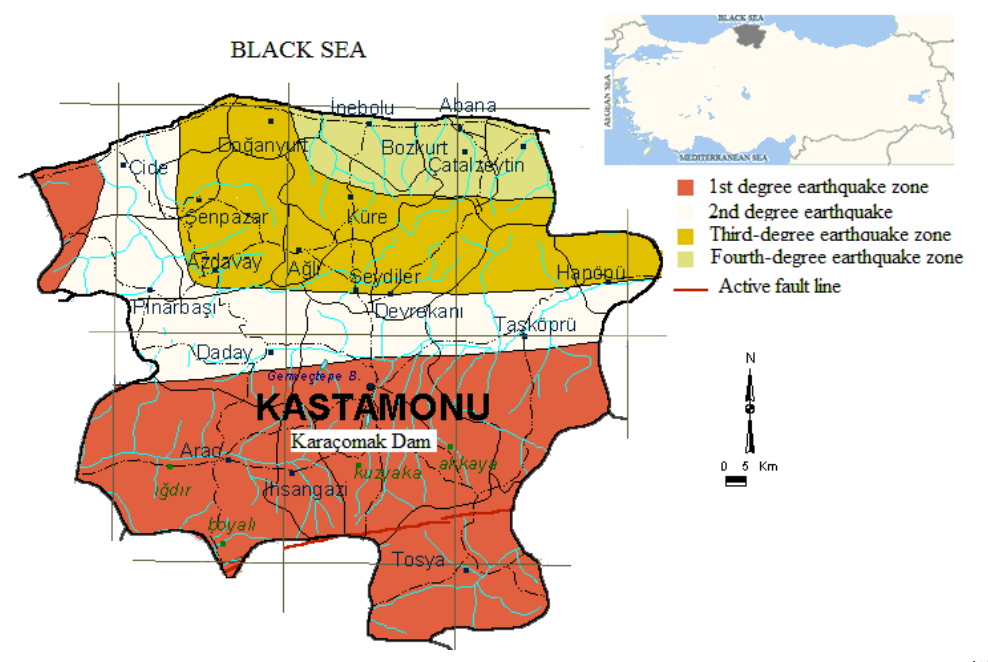

Figure 1. The location of sampling sites and earthquake map of Kastamonu ${ }^{(8)}$. 
radon activity concentrations in the 12 water samples collected from Karaçomak Dam which is household water supply were determined. All the water samples measurements were made in the Nuclear physics laboratory at Kastamonu University. Laboratory measurements were performed on the same day after drawing the samples. The results were recorded in units $\mathrm{Bq}$ $\mathrm{m}^{-3}$ and converted to $\mathrm{Bq} \mathrm{l}^{-1}$. Whole water samples were collected during winter season in 2014.

Radon concentrations of the water samples were measured using the professional radon monitor AlphaGUARD PQ2000 PRO which is a portable radon monitor with high storage capacity. This is an ionization chamber (0.62 l), designed for measuring radon in air, soil and water. AquaKIT, the additional equipment of AlphaGUARD, was used for the water measurements.

AlphaGUARD has ionization chamber whose was also a part of gas cycle. Radon was expelled from water samples (placed in emanation vessel) using the pump in a close gas cycle. The safety vessel was connected with the emanation vessel. All drops would deposit in it if they had got into the gas cycle during the degassing process. This way the stress of the water vapor was minimized for the radon monitor. After that the water was injected into the emanation vessel, and the AlphaGUARD and AlphaPUMP were switched on. The flow rate of the pump was $0.3 \mathrm{l} \mathrm{min}^{-1}$. After $10 \mathrm{~min}$ the pump was switched off and the AlphaGUARD remained switched on for another $20 \mathrm{~min}$, so the radon measurement was continued. The AlphaGUARD monitor worked in a 'flow' mode in a 1 minute. Before every water sample measurement, for a few minutes, the background of empty set-up was measured. Calibration of the measuring system has been carried out by Saphymo (Genitron Instruments, Germany), with a guaranteed stability and accuracy for $5 \mathrm{y}$. Briefly, this measuring system is portable, offers faster reading and accurate measurements. The following equation was used to determined radon concentrations in the water samples (10);

$$
A_{\text {water }}=\frac{\left.A_{\text {air }} \frac{\left(V_{\text {system }}-V_{\text {sample }}\right)}{V_{\text {sample }}}+k\right)-A_{0}}{1000}
$$

where $A_{\text {water }}$ is radon concentration in water sample $\left(\mathrm{Bqm}^{-3}\right), \mathrm{A}_{\text {air }}$ is radon concentration in the set-up after expelling radon from water $\left(\mathrm{Bqm}^{-3}\right), \mathrm{A}_{0}$ is background $\left(\mathrm{Bqm}^{-3}\right), \mathrm{V}_{\text {system }}$ is interior volume of the measurement set-up $(\mathrm{mL}), \mathrm{V}_{\text {sample }}$ is volume of the water sample $(\mathrm{mL})$, and $\mathrm{k}$ is radon distribution coefficient.

$$
k=0.105+0.405 e^{-0.502 \times T\left({ }^{\circ} \mathrm{C}\right)}
$$

\section{RESULTS}

The radon activity concentrations in the residential tap water samples were analyzed for 60 samples in Kastamonu city Centre. In the study area, residential tap water is obtained from surface water. The results for 60 samples categorized into four locations. Table 1 reports the results for the mean radon activity concentrations in residential tap water samples collected from each region of the study area. In dam water the radon activity concentrations were found to range from $2.28 \pm 0.113 \mathrm{~Bq} \mathrm{l}^{-1}$ to $0.034 \pm 0.007 \mathrm{~Bq} \mathrm{l}^{-1}$, with a mean ${ }^{222} \mathrm{Rn}$ activity concentration of $0.741 \pm 0.046 \mathrm{~Bq} \mathrm{l}^{-1}$.

As shown in table 1 , the radon activity concentrations of the residential tap water samples were found to range from $0.025 \pm 0.006$ $\mathrm{Bq} \mathrm{l}^{-1}$ to $0.128 \pm 0.025 \mathrm{~Bq} \mathrm{l}^{-1}$, with a mean ${ }^{222} \mathrm{Rn}$ activity concentration of $0.050 \pm 0.003 \mathrm{~Bq} \mathrm{l}^{-1}$.

As related with radiation dose which people are exposed to, waterborne radon may be a higher risk than all other contaminants in water (13). In tap water, radon may cause to exposures from the inhalation of radon released to air when the water is used and from the ingestion of drinking water. The annual effective dose equivalent AEDE $\left(\mu \mathrm{Sv} \mathrm{y}^{-1}\right)$ for inhalation is calculated using equation 1 :

$$
\begin{gathered}
A E D E\left(\mu S v y^{-1}\right)=A\left(B q l^{-1}\right) \times A W C \times O \times E F \times D C F \\
\times 1000\left(1 / m^{3}\right)
\end{gathered}
$$

where, $\mathrm{A}$ is the ${ }^{222} \mathrm{Rn}$ activity concentration in water $\left(\mathrm{Bq} \mathrm{l} \mathrm{l}^{-1}\right), \mathrm{AWC}$ is the is air water concentration ratio $\left(10^{-4}\right), 0$ is indoor occupancy of 7,000 hours per year, EF is the equilibrium factor (0.4) between radon and its decay products and DCF is the is the dose conversion factor for radon exposure $9\left(\mathrm{nSv} / \mathrm{Bqm}^{-3} \mathrm{~h}\right){ }^{(14)}$.

Int. J. Radiat. Res., Vol. 14 No. 3, July 2016 
The annual effective dose equivalent AEDE $\left(\mu \mathrm{Sv} \mathrm{y}^{-1}\right)$ for ingestion is calculated using equation 2:

$$
\begin{gathered}
A E D E\left(\mu S v y^{-1}\right)=A\left(B q l^{-1}\right) \times 60(l / y) \\
\times 3.5\left(n S v B q^{-1}\right) \quad(2)
\end{gathered}
$$

where $60\left(\mathrm{l} \mathrm{y}^{-1}\right)$ is weighted estimate of water consumption and $3.5\left(\mathrm{nSv} \mathrm{Bq}^{-1}\right)$ is the effective dose coefficient for ingestion (14).

According to UNSCEAR (2000) report, the ingestion of tap water was estimated in the UNSCEAR (1993) Report to be 100, 75, and 501 $\mathrm{y}^{-1}$ by infants, children, and adults, respectively. Assuming the proportion of these groups in the population to be $0.05,0.3$, and 0.65 , the weighted estimate of consumption was determined as $60 \mathrm{ly}^{-1}(14)$.

By using the information given above, the annual effective dose equivalent AEDE ( $\left.\mu \mathrm{Sv}^{-1}\right)$ for inhalation, ingestion and total were calculated for the study area (table 1 ).

The annual effective dose equivalent values for first, second, third and fourth regions varied from 0.0630 to $0.3226 \mu \mathrm{Sv} \mathrm{y}^{-1}, 0.0756$ to 0.1739 $\mu \mathrm{Sv}^{-1}, 0.0882$ to $0.1814 \mu \mathrm{Sv} \mathrm{y}^{-1}$ and 0.0882 to $0.1588 \mu \mathrm{Sv} \mathrm{y}^{-1}$ for inhalation; 0.0053 to 0.0269 $\mu \mathrm{Sv} \mathrm{y}^{-1}, 0.0063$ to $0.0145 \mu \mathrm{Sv} \mathrm{y}^{-1}, 0.0074$ to $0.0151 \mu \mathrm{Sv}^{-1}$ and 0.0074 to $0.0132 \mu \mathrm{Sv} \mathrm{y}^{-1}$ for ingestion, respectively. The mean values for first, second, third and fourth regions were found to be $0.1534,0.1243,0.1186$ and $0.1100 \mu \mathrm{Sv}^{-1}$ for inhalation and 0.0128, 0.0104, 0.0099 and $0.0092 \mu \mathrm{Sv} \mathrm{y}^{-1}$ for ingestion, respectively (table 1). In addition, for the radon exposure from ingestion, the annual effective dose equivalents were calculated separately for infants, children, and adults (table 2).

\section{DISCUSSION}

The results (table 1) show that, for Kastamonu city Centre, the mean ${ }^{222} \mathrm{Rn}$ activity concentration of the residential tap waters is relatively low. Also, both the measured radon activity concentrations in all the residential water samples and the mean value of all the samples were below the internationally recommended safe limit of 4-40 $\mathrm{Bg} \mathrm{l}^{-1}$ (11), the maximum contaminant level (MCL) $\left(300 \mathrm{pCi} \mathrm{l}^{-1}=\right.$ 11.1 $\mathrm{Bq} \mathrm{l}^{-1}$ ) of the US Environmental Protection Agency (3) and the European Union recommended level of $100 \mathrm{Bql}^{-1}$ (11), hence the tap waters of Kastamonu city Centre safe for drinking purposes in terms of radon activity concentrations.

The results from this research indicate that the annual effective dose equivalents due to radon in drinking water are below the WHO

\begin{tabular}{|c|c|c|c|c|c|c|c|}
\hline \multirow[b]{2}{*}{ Region } & \multirow{2}{*}{$\begin{array}{l}\text { Sample } \\
\text { No }\end{array}$} & \multicolumn{3}{|c|}{${ }^{222} \mathrm{Rn}$ Concentrations $\left(\mathrm{Bq} \mathrm{I}^{-1}\right)$} & \multicolumn{3}{|c|}{ Annual Effective Dose Equivalent $\left(\mu S v y^{-1}\right)$} \\
\hline & & 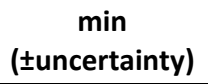 & 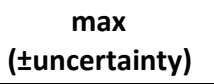 & $\begin{array}{l}\text { mean } \\
( \pm S D)\end{array}$ & Inhalation & Ingestion & Total \\
\hline First & 15 & $0.025 \pm 0.006$ & $0.128 \pm 0.025$ & $0.061 \pm 0.004$ & 0.1534 & 0.0128 & 0.1662 \\
\hline Second & 15 & $0.030 \pm 0.004$ & $0.069 \pm 0.008$ & $0.049 \pm 0.003$ & 0.1243 & 0.0104 & 0.1347 \\
\hline Third & 15 & $0.035 \pm 0.007$ & $0.072 \pm 0.011$ & $0.047 \pm 0.001$ & 0.1186 & 0.0099 & 0.1285 \\
\hline Fourth & 15 & $0.035 \pm 0.005$ & $0.063 \pm 0.009$ & $0.044 \pm 0.001$ & 0.1100 & 0.0092 & 0.1192 \\
\hline \multicolumn{2}{|c|}{ Mean } & \multicolumn{3}{|c|}{$0.050 \pm 0.003$} & 0.1266 & 0.0105 & 0.1371 \\
\hline
\end{tabular}

Table 1. ${ }^{222} \mathrm{Rn}$ activity concentrations in the residential tap water and the annual effective doses.

\begin{tabular}{|c|c|c|c|c|c|c|c|c|c|c|}
\hline \multirow{3}{*}{ Region } & \multirow{3}{*}{$\begin{array}{c}\text { Number } \\
\text { of } \\
\text { Samples }\end{array}$} & \multicolumn{9}{|c|}{ Annual Effective Dose Equivalent $\mu \mathrm{Sv} \mathrm{y}^{-1}$ (ingestion) } \\
\hline & & \multicolumn{3}{|c|}{ infants } & \multicolumn{3}{|c|}{ children } & \multicolumn{3}{|c|}{ adults } \\
\hline & & $\min$ & $\max$ & mean & $\min$ & $\max$ & mean & $\min$ & $\max$ & mean \\
\hline First & 15 & 0.0088 & 0.0448 & 0.0213 & 0.0066 & 0.0336 & 0.0160 & 0.0044 & 0.0224 & 0.0107 \\
\hline Second & 15 & 0.0105 & 0.0242 & 0.0173 & 0.0079 & 0.0181 & 0.0130 & 0.0053 & 0.0121 & 0.0086 \\
\hline Third & 15 & 0.0123 & 0.0252 & 0.0165 & 0.0092 & 0.0189 & 0.0124 & 0.0061 & 0.0126 & 0.0082 \\
\hline Fourth & 15 & 0.0123 & 0.0221 & 0.0153 & 0.0092 & 0.0165 & 0.0115 & 0.0061 & 0.0110 & 0.0076 \\
\hline \multicolumn{2}{|c|}{ mean } & \multicolumn{3}{|c|}{0.0176} & \multicolumn{3}{|c|}{0.0132} & \multicolumn{3}{|c|}{0.0088} \\
\hline
\end{tabular}

Table 2. The annual effective dose equivalent from ingestion for infants, children, and adults. 
recommended reference level of $0.1 \mathrm{mSv}^{-1}$ for water samples (15). Thus, the tap water can be used as drinking water without any radioactive contaminants. A comparison with the radon activity concentrations of tap waters from different studies conducted around the globe is given in table 3.

A comparison of the concentrations obtained in this research with other parts of world indicates that ${ }^{222} \mathrm{Rn}$ activity concentration of the tap water samples is very low except Istanbul (24). The low radon concentrations in water of Kastamonu may be due to a number of factors, e.g. the geological structure, porosity of the soil, meteorological parameters, providing surface reservoirs, etc. On the other hand, the radon values in this study are lower than the action levels recommended by different monitoring agencies of the world, e.g. US EPA, UNSCEAR, EU. Therefore, radon poses comes from waterborne radon no threat to the lives of the people in this locality.

\section{CONCLUSION}

The ${ }^{222} \mathrm{Rn}$ activity concentrations were determined by AlphaGuard PQ 2000 Pro in 60 different residential tap water and 12 dam water samples collected from Kastamonu province. The mean activity concentrations of ${ }^{222} \mathrm{Rn}$ was found for all residential tap water samples and dam water samples. The mean annual effective dose equivalents were calculated. The results may be useful in assessment of exposures and ${ }^{222} \mathrm{Rn}$ doses from tap water using drinking purposes. Also, the results obtained from this research is baseline which can be used to evaluate possible future changes and will be provide a good baseline for setting standards for water quality.

\section{Conflict of interest: Declared None}

\section{REFERENCES}

1. Ojo TJ and Ajayi IR (2014) A Review on Environmental Radon and Its Potential Health Risk on Humans. IOSR $\mathrm{J}$ Environ Sci Tox Food Techno, 8: 1-8.

2. Lee J and Kim G (2006) A simple and rapid method for analyzing radon in coastal and ground waters using a radon-in-air monitor. J Environ Radioact, 89: 219-228.

3. United States Environmental Protection Agency (USEPA) (1994) Report to the United States Congress on Radon in Drinking Water, Multimedia Risk and Cost Assessment of Radon. United States Environmental Protection Agency,

Table 3. ${ }^{222} \mathrm{Rn}$ activity concentrations in tap waters from different parts of world, compared with those of the present study.

\begin{tabular}{|c|c|c|}
\hline Country & Radon Activity $\left(\mathrm{Bq} \mathrm{I}^{-1}\right)$ & References \\
\hline Jordan & $2.5-4.7$ & Al-Bataina et al. ${ }^{(16)}$ \\
\hline Venezuela & $0-2$ & Horvath et al. ${ }^{(17)}$ \\
\hline Brazil & $0.39-0.47$ & Marques et al. ${ }^{(18)}$ \\
\hline Kenya & $0.80-4.70$ & Otwoma and Mustapha ${ }^{(19)}$ \\
\hline Algeria & $0.26-2.28$ & Amrani and Cherouati ${ }^{(20)}$ \\
\hline Cyprus & $0.1-2.00$ & Sarrou and Pashalidis ${ }^{(21)}$ \\
\hline Egypt & $0.007-2.33$ & Abbady et al. ${ }^{(22)}$ \\
\hline India & $0.084-0.83$ & Kant et al. ${ }^{(23)}$ \\
\hline \multicolumn{3}{|l|}{ Cities of Turkey } \\
\hline İstanbul & $0.019-0.048$ & Karahan et al. ${ }^{(24)}$ \\
\hline Denizli & $0.67-25.90$ & Ereeş et al. ${ }^{(25)}$ \\
\hline Afyonkarahisar & $0.7-31.7$ & Yalım et al. ${ }^{(26)}$ \\
\hline İzmir-Dikili & $0.029-3.08$ & Yarar et al. ${ }^{(27)}$ \\
\hline Bursa & $0.91-53.64$ & Tarım et al. ${ }^{(28)}$ \\
\hline Amasya & $0.28-2.4$ & Öner et al. ${ }^{(29)}$ \\
\hline Tokat & $0.09-1.30$ & Yiğitoğlu et al. ${ }^{(30)}$ \\
\hline Kütahya & $0.1-48.6$ & Şahin et al. ${ }^{(31)}$ \\
\hline Konya & $1.44-27.45$ & Erdoğan et al. ${ }^{(32)}$ \\
\hline Zonguldak & $0.32-88.22$ & Koray et al. ${ }^{(33)}$ \\
\hline Yalova & $0.21-5.82$ & Tabar and Yakut ${ }^{(34)}$ \\
\hline Kastamonu/Turkey & $0.025-0.128$ & Present Study \\
\hline
\end{tabular}


Office of Water, 4601, EPA 811-R-94-001.

4. Pirsaheb M, Najafi F, Khosravi T, Hemati L, (2013) A Systematic Review of Radon Investigations Related to Public Exposure in Iran. Iranian Red Cres Med J, 15(11): e10204.

5. Binesh A, Mohammadi S, Mowlavi AA, Parvaresh P (2010) Evaluation of the radiation dose from radon ingestion and inhalation in drinking water. Int J Water Res Environ Eng, 2: 174-178.

6. United States Environmental Protection Agency (USEPA) (2010) Risk Assessment of Radon in Drinking Water, Initial EPA Perspectives on NAS Report: Risk Assessment of Radon in Drinking Water.

7. World Health Organization (WHO) (2009) WHO handbook on indoor radon a public health perspective, 1: 4.

8. MTA, General Directorate of Mineral Research and Exploration (2012) Seismic zonation map. http:// www.mta.gov.tr/v2.0/deprem/index.php? id=dep_bol_harita.

9. Republic of Turkey Governorship of Kastamonu. http:// www.kastamonu.gov.tr/cografi-yapi.asp, 2014.

10. Correa JN, Paschuk SA, Schelin HR, Barbosa L, Sadula T, Matsuzaki CA (2009) Measurements of radon concentration level in drinking water at urban area of Critiba (Brazil). International Nuclear Atlantic ConferenceINAC 2009, September 27 to October 2, Rio de Janeiro, Brazil, ISBN:978-85-99141-03-8.

11. United Nations Scientific Committee on the Effects of Atomic Radiation (UNSCEAR) (1993) 1993 Report to the General Assembly, with scientific annexes. United Nations sales publication E.94.IX.2. United Nations, New York.

12. European Union (EU) (2001) Commission Recommendation of 20 December 2001 on the Protection of the Public Against Exposure to Radon in Drinking Water Supplies. Official Journal of the European Communities, $L$ 344: 85-88.

13. Vitz E (1991) Towards a standard method for determining waterborne radon. Health Phys, 60: 817-829.

14. United Nations Scientific Committee on the Effects of Atomic Radiation (UNSCEAR) (2000) UNSCEAR 2000 Report to the General Assembly, with scientific annexes, Vol. 1, Sources, Annex B, Exposures from natural radiation sources, United Nations, New York.

15. World Health Organization (WHO) (2011) Guidelines for Drinking Water Quality, Recommendations, Fourth Edition, Geneva, Switzerland.

16. Al-Bataina BA, Ismail AM, Kullab MK, Abmurad KM, Mustafa H (1997) Radon measurements in different types of natural waters in Jordan. Radiat Meas, 28: 591-594.

17. Horvath A, Bohus LO, Urbani F, Marx G, Piroth A, Greaves ED (2000) Radon concentrations in hot spring waters in northern Venezuela. J Environ Radioact, 47: 127-133.

18. Marques AL, Santos W, Geraldo LP (2004) Direct measurements of radon activity in water from various natural sources using nuclear track detectors. Appl Radiat
Isot, 60: 801-804.

19. Otwoma D, Mustapha AO (1998) Measurement of ${ }^{222} \mathrm{Rn}$ Concentration in Kenyan Groundwater. Health Phys, 74: 91.

20. Amrani D and Cherouati DE (1999) Health effects from radon-222 in drinking water in Algiers. J Radiol Prot, 19: 275.

21. Sarrou I and Pashalidis I (2003) Radon Levels in Cyprus. J Environ Radioact, 68: 269.

22. Abbady A, Ahmed NK, Saied MH, El-Kamel AH, Ramadan S (1995) Variation of ${ }^{222} \mathrm{Rn}$ concentration in drinking water in Qena. Bull Fac Sci, 24: 101-106.

23. Kant K, Upadhyay SB, Chakarvarti SK (2005) Alpha activity in Indian thermal springs. Iran J Radiat Res, 2 (4):197-204.

24. Karahan G, Öztürk N, Bayülken A (2000) Natural Radioactivity in Various Surface Waters in Istanbul, Turkey. Wat Res, 34 (18): 4367-4370.

25. Erees FS, Aytas S, Sac MM, Yener G, Salk M (2007) Radon concentrations in thermalwaters related to seismic events along faults in the Denizli Basin,Western Turkey. Radiat Meas, 42: 80- 86.

26. Yalım HA, Sandıkcıoğlu A, Unal R, Orhun O (2007) Measurements of radon concentrations in wellwaters near the Aksehir fault zone in Afyonkarahisar, Turkey. Radiat Meas, 42: 505- 508.

27. Yarar Y, Günaydi T, Çelebi N (2006) Determination of Radon Concentrations of The Dikili Geothermal Area in Western Turkey. Radiat Prot Dosim, 118 (1): 78-81.

28. Tarim UA, Gurler O, Akkaya G, Kilic N, Yalcin S, Kaynak G, Gundogdu O (2012) Evaluation of radon concentration in well and tap waters in Bursa, Turkey. Radiat Prot Dosim, 150 (2): 207-212.

29. Öner F, Yalim HA, Akkurt A, Orbay M (2009) The Measurements of radon concentrations in drinking water and The Yesilırmak river water in the area of Amasya in Turkey, Radiat Prot Dosim, 133(4): 223-226.

30. Yiğitoğlu I, Öner F, Yalim HA, Akkurt A, Okur A, Özkan A (2010) Radon concentrations in water in the region of Tokat city in Turkey. Radiat Prot Dosim, (2-4):358-362.

31. Şahin L, Çetinkaya H, Saç MM, Içhedef M (2013) Determination of radon and radium concentrations in drinking water samples around the city of Kütahya. Radiat Prot Dosim, 155 (4): 474-482.

32. Erdoğan M, Eren N, Demirel S, Zedef V (2013) Determination of radon concentration levels in well water in Konya, Turkey. Radiat Prot Dosim, 156 (4): 489-494.

33. Koray A, Akkaya G, Kahraman A, Kaynak G (2014) Measurements of radon concentrations in waters and soil gas of Zonguldak, Turkey. Radiat Prot Dosim, 162 (3): 375381.

34. Tabar E and Yakut H (2014) Radon measurements in water samples from the thermal springs of Yalova basin, Turkey. J Radioanal Nucl Chem, 299: 311-319. 